\title{
THE ILO CONCEPT OF ECONOMIC DEPENDENCE IN SLOVENIAN LABOUR LAW
}

The objective of this article is to highlight the phenomenon of economic dependence inasmuch as it has been established in various publications of the ILO to be an element of the personal scope of national labour legislation. Following the example of Spain, in Slovenia the concept of economic dependence has been a part of labour legislation since 2013. In addition to providing an outline of the legislation in force, the author identifies various weaknesses of the regulation in practice that have become apparent since the implementation of the institution of economic dependence. The author critically calls attention to the identified weaknesses and offers possible alternatives for consideration. Regardless of the fact that the author in principle agrees that economic dependence is recognised as an element that justifies limited labour law protection of economic dependents, he expresses reservations regarding the idea of the Slovenian legislature to adopt a special act regulating the position of economic dependents.

Keywords: economic dependence; dependent self-employed persons; precarious forms of labour; personal scope of labour law

* Luka Tičar, Ph. D., Assistant Professor, Faculty of Law, University of Ljubljana, Poljanski nasip 2, 1000 Ljubljana, Slovenia; luka.ticar@pf.uni-lj.si;

ORCID ID: orcid.org/0000-0001-5793-6270 


\section{INTRODUCTION}

In expert circles, economic dependence is once again a frequent topic of discussion; economic dependence was introduced into Slovenian labour regulation with the last amendment to the Employment Relationships Act in 2013 (Zakon o delovnih razmerjih - ZDR-1; hereinafter referred to as: ERA-1: Employment Relationships Act). ${ }^{1}$ The Slovenian legislature followed the Spanish model of the regulation of economically dependent self-employed persons and introduced in the ERA-l the concept of economic dependence and defined the term economic dependent. Discussions on economic dependence in Slovenia take place in the broader context of the phenomenon of the personal scope of labour law, within the framework of which a predominant part is devoted to disguised employment relations. ${ }^{2}$ This article will nevertheless focus on the standard employment relationship only in the following section, where the concepts of personal subordination - as a key element of the employment relationship - and economic dependence will be clearly delimited.

With regard to the characteristics of the labour market in Slovenia, attention is often focused on the concepts of the precarious nature of work, precariousness, and precarious forms of labour, and therefore in the conclusion of this article the position of economic dependents in Slovenia will also be assessed in the light of the risk of evolving into precariousness. The author will follow seven areas of potential insecurity that were identified by the ILO in its global report published in 2016 as possible factors leading to precariousness. ${ }^{3}$

1 Official Gazette RS, Nos. 21/2013, 52/2016.

2 For a while now, the Slovenian labour market has been affected by the fact that civil law contracts are often concluded for work carried out in person. This is not unlawful in and of itself; however, it does bear a certain risk of unlawfulness. In order to carry out work in person according to the instructions and under the supervision of the employer, the most appropriate and in Slovenia the only lawful basis is namely an employment contract, which in the Slovenian labour law system is a contract under labour law (for more detailed explanation of this see Končar, P., The concept of Employee: The position in Slovenia, in: Wass, B. (ed.), Restatement of Labour Law in Europe, Hart Publishing, Bloomsbury, 2017, p. 641). Naturally, not every performance of work in person is also carried out according to the instructions and under the supervision of the employer and therefore in cases lacking personal subordination a civil law legal basis can be entirely appropriate and lawful. Such cases may concern work in circumstances of economic dependence, a form of work that is as well regulated by the ERA-1 and carried out on the basis of a civil law contract.

3 Non-standard employment around the world, International Labour Office, 2016. 


\section{PERSONAL SUBORDINATION AS A STANDARD ELEMENT OF AN EMPLOYMENT RELATIONSHIP AND ITS RELATIONSHIP TO ECONOMIC DEPENDENCE ${ }^{4}$}

In order to understand the concept of economic dependence as applied in the documents of the ILO and in the ERA-l with regard to regulating the position of economic dependents, it is useful to first outline the notion of the personal subordination of a worker ${ }^{5}$ in relation to the employer. The latter is namely still a fundamental starting point of the traditional employment relationship. The employment relationship remains the most appropriate legal environment for performing work in person according to the instructions and under the supervision of the employer. ${ }^{6}$ The latter stands regardless of the fact that all over the world there are animated discussions and considerations on non-standard forms of work, on various forms of zero-hour contracts ${ }^{7}$, on the position of workers using online platforms to perform work, etc. ${ }^{8}$, everything under the notion and influence of sharing economy. ${ }^{9}$ Therefore we can agree on many thoughts of Prassl, discussing the bright and the dark sides of the modern work patterns. ${ }^{10}$

Developmental changes in the organisation of work in the last decade and more that have encouraged the expansion of various forms of work, and conse-

4 For more, see: Tičar, L., Nova koncepcija ekonomske odvisnosti kot možen dejavnik osebne veljavnosti delovnega prava, Zbornik znanstvenih razprav, Vol. 71, 2011, pp. 175-203.

5 Slovenian labour law does not know and does not use the term employee. The worker is a person that concludes an employment contract with the employer and is personally subordinated to employer. Therefore the legislation does not distinct between worker and employee. With use of the term worker we address a person involved in traditional employment relationship. For further explanation and for historical origins of this concept see Končar, op. cit. (fn. 2), pp. 645, 646.

6 With reference to such, it is usually referred to the content and global significance of the ILO Recommendation concerning the employment relationship (No. 198). This Recommendation provides a basis for reducing the erosion of labour law and for becoming aware of its fundamental starting points and axioms.

7 See for instance Adams, A.; Freedland, M.; Prassl, J., The "zero hour contract": regulating casual work, or legitimating precarity, Oxford University working paper, 2014.

8 For more see: Prassl, J.; Risak, M., Uber, TaskRabbit\&Co: Platforms as employers?, Rethinking the legal analysis of crowd work, Comparative Labor Law and Policy Journal, Forthcoming, Oxford Legal Studies Research Paper No. 8/2016.

9 For more economic perspective view see: Basselier, R.; Langenus, G.; Walrawens, L., The rise of sharing economy, NBB Economic Review, No. 3, 2018.

10 Prassl, J., Humans as a service: The promise and perils of work in the gig economy, Oxford University Press, Oxford, 2018. 
quently the legal basis for such, have led to discussions on the appropriate nature of the traditional personal scope of labour law..$^{11}$ The fact is that the application of labour law to the concept of a traditional (production) worker and thereby the traditional concept of the personal subordination of the worker no longer suffices, as an increasing number of the active working population can no longer be unambiguously defined as workers in the traditional sense; i.e. as personally subordinate and economically dependent persons who conclude an employment contract with the employer to carry out work. The share of persons who carry out work under civil law contracts and not under employment contracts, but under conditions and circumstances similar to those of an employment relationship, is becoming ever larger and consequently more important. ${ }^{12}$ We are thus faced with relationships in which the characteristics of subordinate employment relationships and the characteristics of independent contractual relationships, i.e. self-employment, collide. An increasingly important group of workers are persons who carry out work in person, over a longer period of time, for payment, but not in circumstances of subordination, as their clients do not exercise any of three powers over such persons, i.e. normative power, the power to provide directions, and the power to discipline. A central element of the relationship between such persons and their clients can be economic dependence on a single client, which in numerous European countries has already encouraged at least expert discussions regarding its relevance to the possible broadening of the personal scope of labour law. The ILO and theory place the group of economic dependents that formally appear as personally independent contractors into the group of persons that need labour law protection. ${ }^{13}$ The argument for such position lies in the fact that there are distinct negative effects of the lack of

11 On certain issues regarding the personal scope of labour law that surpass the phenomenon of economic dependence, see: Tičar, L., Temeljna vprašanja kroga oseb delovnopravnega varstva, Delavci in delodajalci, Vol. 2-3, 2008, pp. 329 - 343, or Senčur Peček, D., Samozaposleni, ekonomsko odvisne osebe in obstoj delovnega razmerja, Delavci in delodajalci, Vol. 2-3, 2014, pp. 201 - 221.

12 According to statistical data, taken by the Statistical Office of the Republic of Slovenia it is estimated that there were in year 2012 among self-employed persons 7,9\% economic dependants (app. 9000), while in the year 2016 the share has grown to the 12,7\% (app. 14.000). See: https://www.stat.si/StatWeb/News/Index/7302 (7.10.2019).

13 Treu once said that “... labour law has to show a greater capacity of adaptation if it wants to continue to play a significant role in the new social and economic environment." (The scope of employment relationship, Report (V), 2003, available at: http://www.ilo.org/public/english/standards/relm/ilc/ilc9l/pdf/rep-v.pdf, p. 10 (3.10.2019)). On this standpoint originates a need to identify group of active persons that need at least some labour protection. In this regard we are emphasizing, as well as Treu did, the role of labour law, which is to ensure labour protection to 
protection of economic dependents and a distinct negative effect of the termination of the business relationship between an economic dependent and the client thereof. A client, for example, is not limited by (the cogent) rules of labour law in a business decision to terminate the legal relationship with the contractor as is an employer when workers in an employment relationship are dismissed.

The phenomenon of economic dependence surpasses the doctrinal delimitation of subordinate work from independent work, i.e. an employment relationship from a civil law relationship, where personal, legal subordination is mainly at issue. Economic dependence constitutes a specific condition that is established during a permanent relationship between a person that carries out work and the client. ${ }^{14}$ Therefore, economic dependence can be completely independent from personal (in)dependence and is consequently more difficult to recognise. Economic dependence is either connected to personal subordination or is independent and as such it is either considered a i) part of the broader concept of subordination, an ii) entirely independent element of the employment relationship, or only an iii) element for ensuring labour law protection. ${ }^{15}$ The proposition that economic dependence should be recognised the status of an independent defining element of the employment relationship and as such connected to the status of the worker is probably too extreme to accept, regardless of the fact that in theory there are often tendencies to substitute personal subordination with economic dependence. Theoreticians such as Cuche, already in the first half of the past century ${ }^{16}$, and Wank ${ }^{17}$ saw supporting arguments for such proposition in the fact that primarily economic, i.e. financial, dependence was a reason for the development of labour law and social security law, as the fact that a person depends on someone in order to survive is a more important societal fact than following someone's instructions on how to carry out work. From the perspective of contemporary theoretical discussions in the sphere of labour law, the proposition to substitute subordination with economic dependence is demonstrated

those that need it, in spite of the fact that they perhaps cannot be classified as traditional subordinated workers.

14 Similarly on the notion of economic dependence Williams, C. C.; Horodnic, I. A., Dependent Self-employment. Theory, Practice and Policy, Elgar Publishing, Cheltenham, 2019, pp. $2-5$.

15 Tičar, L., Nove oblike dela - kdo in v kakšnem obsegu naj uživa delovnopravno varstvo, Manet, Ljubljana, 2012, p. 221.

16 Supiot, A., Beyond employment, Oxford University Press, Oxford, 2005, p. 14.

17 Wank, R., "Germany", Labour Law in Motion: Diversification of the labour force \& Terms and Conditions of Employment (Reports given at the 7th Tokyo Seminar, March 2004), Kluwer Law, 2005, pp. $19-26$. 
as a tendency towards a broader personal scope of labour law. ${ }^{18}$ With regard to the latter, the definition of the worker plays a central role.

Regarding the contemporary understanding of the concept of subordination as personal or legal subordination, regardless of the tendencies of certain theoreticians, we are of the opinion that the phenomenon of personal subordination is a mere fact of labour law. It should be accepted as such; we cannot agree with the opinion that in today's societal and economic circumstances there is no longer a suitable place for personal subordination. The starting point for such a view is the meaning that subordination has not only with reference to establishing the existence of an employment relationship, if there is doubt or a dispute as to this circumstance, but also with reference to the labour law protection that is afforded workers in exchange for their subordinate position. ${ }^{19}$ However, we believe that it is necessary to accept the fact that in light of the ever more limited applicable value of the instructions and supervision provided by the employer as traditional indicators of personal subordination, an important position is given to the inclusion of the worker in the organised work process. ${ }^{20}$ We do not equate the latter with the concept of personal subordination, but we see such merely as a factor that contributes to the establishment of the existence of personal subordination and consequently an employment relationship.

From a historical point of view, the economic dependence of the worker was also a reason for the development of labour law, whose objective is to ensure workers a decent life and work through the guarantees stemming from an employment relationship. Thus, economic dependence, in addition to personal subordination, represents an important worthy element of labour law. A worker was, is, and will be not only personally subordinate to his or her employer, but also economically dependent thereon. Nevertheless it is important to consider

18 An antipode to the tendency towards a broader personal scope of labour law is the tendency towards limiting, i.e. narrowing, its personal scope. With reference to such, the concept of permanent legal subordination should be underlined, which in French labour law entails a restrictive definition of the concept of the worker and consequently excludes many individuals from the sphere of labour law protection, e.g. fixed-term employees. For more on this, see: Supiot, supra n. 16, pp. 13, 14.

19 For more on this, see: Končar, P., in: Bečan, I. et al., Zakon o delovnih razmerjih s komentarjem, GV Založba, Ljubljana, 2008, p. 38.

20 Inclusion in the organised work process means for instance determination of time and place of work by the employer, to some extent also usage of the work resources (means of production), owned by the employer etc. In some labour law systems, such as Croatian, in this context the term of organizational subordination is used. See Grgurev, I., Ugovor o radu, in: Potočnjak, Ž. (ur.), Radni odnosi u RH, Pravni fakultet u Zagrebu, Organizator, Zagreb, 2007, p. 15. 
that in Slovene labour law economic dependence is not a defining element or "basic component" ${ }^{21}$ of employment relationship. For establishment of an employment relationship theoretically suffice existence of a personal or legal subordination, though a certain person might be economically independent. Taking this into consideration the phenomenon of economic dependence, as discussed below in this article, will not be examined as a condition of a personally subordinate worker, but will be treated as completely independent from the concept of subordination.

\section{THE CONCEPT OF ECONOMIC DEPENDENCE}

The concept of economic dependence can be understood as the condition of dependence of an individual stemming from an income that he or she receives from his or her, usually only, client. The definition encompasses an understanding of the phenomenon, as it was developed by the ILO for the needs of the discussed issue of the personal scope of labour law. ${ }^{22}$ In this article, the term economic dependence will be used exclusively with reference to the legal position of self-employed persons or contractors, thus persons who are not in an employment relationship. These are persons regarding whom personal subordination towards a client cannot be identified, while simultaneously they are also not employers. That means they carry out work, as a general rule, in person, directly and alone, without any help from anybody. In this article the concept of economic dependence will also not be connected with concealing the real legal nature of an individual contractual relationship. In order to determine whether a person, regardless of the existing civil law contract, is in fact in an employment relationship, the element of economic dependence, as a defining element of the employment relationship, is, as mentioned above, not necessary.

Economic dependence is an increasingly important element of contemporary labour law, while in Slovenian legislation it did not receive particular attention until the amendment of the ERA-I. As the ERA-I retained the concept of the employment relationship, the fact that recognition was also given to economic dependence can be in principle regarded as a positive development. We believe that economic dependence deserves to be placed in the normative framework of national labour law. Regardless of the form or manner of placing economic dependence in the context of employment relations, and therewith the labour

21 The term used by Končar (Končar, op. cit. (fn. 2), p. 649).

22 See: The scope of employment relationship, Report (V), available at: http://www.ilo. org/public/english/standards/relm/ilc/ilc9l/pdf/rep-v.pdf, pp. 28, 29 (3.10.2019). 
law protection that the legislature should choose to follow, it is clear that thereby the boundaries of the traditional employment relationship are inevitably crossed. Economic dependents are namely deemed self-employed persons who carry out work as formally and in fact personally independent persons, thus outside the realm of the traditional employment relationship as defined in the ERA-l. Economic dependents are, for example, sole proprietors who work on the basis of a contract with only one client and do not have employees but carry out work themselves, or, for example, persons who as contractors work with only one client or receive at least the majority of their income from one client. In the examples mentioned above, such persons who carry out work are personally independent but depend on their clients economically, thus existentially.

An attempt to recognise economic dependence as an element of labour law protection entails that it traverses into the sphere of civil law. The latter opens a space in which the distinctively contradictory interests of the actors on the labour market collide. The legislature, i.e. the state, decides on the manner of regulating this area depending on its evaluation of the importance of individual interests. At least two approaches to the legislative regulation of the phenomenon of economic dependence are possible: i) economic dependence is regarded as a defining element of the employment relationship, or ii) economic dependence is regarded as a factor for recognising certain elements of labour law protection. The ERA-I applied the latter. Also in the international context, economic dependents are predominantly treated in a manner such that they are recognised or afforded only a certain part of labour law protection. ${ }^{23}$ By such treatment, national legislation by no means interferes with the established methods of

23 Such an approach is undertaken for instance in Spain (see Garcia Murcia, J.; Rodriguez Cardo, A., The concept of Employee: The position in Spain, in: Wass, B. (ed.), Restatement of Labour Law in Europe, Hart Publishing, Bloomsbury, 2017, pp. 673, 674), UK (where economic dependency somehow is part of their concept of worker and dichotomy of employee-worker; see Jones, B.; Prassl, J., The concept of Employee: The position in the UK, in: Wass, B. (ed.), Restatement of Labour Law in Europe, Hart Publishing, Bloomsbury, 2017, pp. 747 - 769), in Germany (where the concept of an employee-like person or quasi-salaried worker has a long tradition; see Wass, B., The concept of Employee: The position in Germany, in: Wass, B. (ed.), Restatement of Labour Law in Europe, Hart Publishing, Bloomsbury, 2017, p. 273, 274), in Italy (with well known "para-subordinate workers" or so called "coordinated work relationship"; see Ales, E., The concept of Employee: The position in Italy, in: Wass, B. (ed.), Restatement of Labour Law in Europe, Hart Publishing, Bloomsbury, 2017, pp. 371 - 374). Austrian law is also familiar with the notion of an employee-like person, but by the contrast to the states mentioned they do not enjoy classic workers' rights, such as the right to paid leave, limited working hours, etc. See Brameshuber, E., The "personal work relationship" in Austria, European Labour Law Journal, Vol. 10, no. 3, 2019, pp. 187 - 197. 
the labour law protection of workers in standard employment relationships. By merely ensuring individual elements of such protection to economic dependents they are left in the civil law sphere, and thus labour law as such, as a general rule, does not apply to them. In labour law legislation such persons are deemed personally independent.

In the Slovenian legislation, in certain instances a similar manner of legislative treatment has been applied for a long time (e.g. the work of children, primary and secondary school students, etc., or in relation to the system for ensuring safe and healthy work, which is intended for a broader circle of persons $\left.{ }^{24}\right)$; since the adoption of the ERA-1 it has also applied to economic dependents. Economic dependence is similarly regulated in Spanish legislation, which introduced the new legislative category of economically dependent self-employed persons, determined conditions for such, and also determined the legal framework of the labour law position of such persons. ${ }^{25}$

The discussed manner of regulating economic dependence depends on two important sets of decisions. The first set of decisions refers to the manner of determining the circle of economic dependents, i.e. either by a clear legislative definition of economic dependence or by listing groups of professions that should receive special treatment. A common starting point of the first set of decisions is that economic dependents are persons who are not and cannot be defined as subordinated workers. The second set of decisions, on the one hand, refers to determining the elements of labour law protection for these persons and, on the other hand, the decision whether everyone should be afforded the same

24 In the Slovenian legal order, such manner of providing protection was regulated in the Employment Relationships Act (Official Gazette RS, Nos. 42/2002, 103/2007 - hereinafter referred to as: ERA) formerly in force, and is currently regulated in the Health and Safety at Work Act in force (Official Gazette RS, No. 43/2011 - hereinafter referred to as: ZVZD-1). The ERA envisaged certain rights for children, primary and secondary school students, and higher education students when carrying out work that is otherwise envisaged for workers in an employment relationship. These are the rights referring to working time, breaks, rest, prohibitions on carrying out certain work, etc. On the other hand, however, by determining a broad personal scope of application and a definition of the worker that is the broadest in the Slovenian legal order, the ZVZD-1 ensures the system of safe and healthy work with regard to all persons who carry out work on any legal basis or who are merely present in the work process.

25 For an outline of the Spanish regulation, see: Barrios Baudor, G. L., Travail autonome "economiquement dependent" en Espagne, Bulletin de droit comparé du travail et de la sécurité sociale, Comptrasec, 2008, pp. 43 - 64, or see: Cabeza Pereiro, J., The Status of Self-employed Workers in Spain, International Labour Review, Vol. 148, No. 1, 2008, pp. $91-99$. 
protection. The European Commission was faced with the latter dilemma in a similar sense when in 2006 it drafted the Green Paper-Modernising labour law to meet the challenges of the 21 st century ${ }^{26}$, namely: Is there a need for a "floor of rights" dealing with the working conditions of all workers regardless of the form of their work contract? What would be the impact of such minimum requirements on job creation as well as on the protection of workers?

\section{THE REGULATION OF ECONOMIC DEPENDENTS IN SLOVENIA}

\section{4.l. The definition of an economically dependent self-employed person}

In the Art. 213 of the ERA-1, an economic dependent is defined as "a self-employed person who on the basis of a civil law contract performs work in person, independently, and for remuneration for a longer period of time in circumstances of economic dependency and does not employ workers. Economic dependency means that a person receives at least $80 \%$ of his or her annual income from the same contracting entity."

In this short and concise definition the following elements of the concept of an economic dependent can be identified:

- self-employment;

- the existence of a civil law contract;

- the performance of work in person, independently, and over a longer period of time;

- the existence of economic dependence;

- the prohibition on employing other workers.

The concept of self-employment is used in numerous legal and societal areas and in numerous legal sources, which, however, define the concept of self-employment or a self-employed person, as a general rule, for their specific needs. Therefore, it would be useful if the legislature defined this concept for the needs of applicability in the ERA-I in its introductory provisions. A dilemma that can arise with reference to the concept of a self-employed person is whether such includes merely self-employed persons with a registered activity (e.g. sole

26 Green Paper - Modernising labour law to meet the challenges of the 21st century, COM (2006) 708 final, Brussels, 22. 11. 2006. This document shows similar activities at the level of the EU as are at the level of the ILO, as shown in numerous documents and reports as well as the adopted Recommendation concerning employment relationships (No. 198). 
proprietors pursuant to the Companies $\mathrm{Act}^{27}$ ) and persons who perform independent activities (e.g. free lance journalists) and who are registered in the registers of independent activities (e.g. the register of free lance journalists), or whether such also includes persons who perform work within the scope of a civil law relationship but do not have the status of a self-employed person. ${ }^{28}$ In our opinion, taking into consideration not only the legislative text but also the goal of the legislature, the concept of a self-employed person must be understood in a broader sense. In order to be recognised the status of an economic dependent it is thus not necessary for a person to also have the status of a self-employed person in the public law sense.

A concluded civil law contract as an element for defining an economically dependent person, on the one hand, emphasises the absence of an employment contract, which is the only contract in the Slovenian legal system that is not a civil law contract ${ }^{29}$, while, on the other hand, emphasis on a civil law contract can indirectly be understood as the inability to recognise the status of a worker to an individual economic dependent.

The latter must be directly identified from the requirement of independent work, whose primary purpose is to underline the independence of a self-employed person when carrying out work or the absence of personal subordination, which is one of the elements of an employment relationship. A self-employed person that has the status of an economic dependent will, by the nature of things, not receive such clear and binding instructions as workers receive, nor will they be subjected to such strict supervision as are workers. This element thus clearly indicates that an economic dependent does not meet the conditions for recognition of the status of a worker, as already at the outset it denies the possibility of the existence of subordination. In other words, this entails that for all self-employed persons the ERA-l retains the possibility that an employ-

27 Zakon o gospodarskih družbah, Official Gazette RS, No. 65/2009 - official consolidated text with amendments - ZGD-1 (Companies Act).

28 This concerns a publicly recognised status that an individual, i.e. a natural person, obtains either by registering an activity (s.p. - denoting Sole Proprietor) or by registering a certain profession (e.g. a free-lance journalist) that this individual carries out in person, exclusively, and for profit. For more on this, see: Tičar, op. cit. (fn. 15), pp. 163, 164.

29 The Slovenian legal system is marked by the fact that labour law is an independent legal discipline, separate from civil law. Therefore, an employment contract is a contract of labour law, while all other contracts that are concluded for performing work in person or providing services in person are contracts of civil law. Thus, in cases in which civil law contracts are concluded, the rules of labour law and the protection that they entail do not apply. 
ment relationship is established if the circumstances in which work is carried out indicate the existence of all of the defining elements of an employment relationship as determined by the ERA-I. Such cases thus concern disguised employment relationships.

Carrying out work in person and over a longer period of time, as elements of economic dependence, on the one hand show that certain work is carried out exclusively by an individual self-employed person, and, on the other hand, that for economic dependence to arise a certain amount of time is needed. It would namely be inappropriate if economic dependence were recognised to a self-employed person already after, for example, the first job done for a client. The compulsory element of economic dependence that work must be carried out in person is additionally and explicitly emphasised (repeated) by the incompatibility of the concept of economic dependence with hiring employees, while other self-employed persons may also be employers and fulfil their contractual obligations towards a client through their workers. From here stems the prohibition on employing others.

Economic dependence is defined as a circumstance wherein at least $80 \%$ of the annual income of the self-employed person comes from the same client. We are of the opinion that a decision of a legislator for $80 \%$ is appropriate, as it seems appropriate a decision of a Spanish legislator as well, determining economic dependence with at least $75 \%$ of the annual income coming from the same client. ${ }^{30}$ A more important circumstance than determining a specific percentage is that it is not required for the existence of economic dependence that income is received exclusively from one client; it is true, however, that an economically dependent self-employed person may receive income only from one client. With reference to such, it must be taken into account that economically dependent self-employed persons are persons that are independent in carrying out their work. Therefore, it is completely natural that they may receive a certain share of income by providing services also to other clients.

\subsection{The scope of labour-law protection}

Possibly more important for the legislature than the definition of the concept of economic dependence is the determination of the type and scope of protection that economic dependents should enjoy. Comprehensive regulation of the phenomenon of economic dependence is thus completed by determining the

30 Art. 11 Estatuto del Trabajo Autonomo, Ley 20/2007 (Self-employed Persons Act); accessible on: https://www.boe.es/buscar/act.php?id=BOE-A-2007-13409 (3.10.2019). 
elements of labour law protection that economic dependents should enjoy. With reference to such, the legislature should be aware that the scope of labour law protection undoubtedly influences the functioning of the labour market, especially the actions of employers and clients. The more the position of economic dependents is similar to the position of workers, the greater the reservations of potential clients towards business cooperation with such persons. Perhaps, although not necessarily, distinctly favourable treatment of economic dependents would (again) increase the level of the traditional employment of workers. Determining the type and scope of labour law protection at the legislative level inevitably results in substantial changes in the functioning of the labour market. Regardless of the final solution, establishing protection for this group of persons is not only appropriate, but, taking into consideration the function of labour law ${ }^{31}$, also necessary.

Protection from unjustified termination of business cooperation between an economic dependent and a client should be identified as the first and probably the most important element of labour law protection. Knowing that a client cannot terminate the contractual relationship at any time for any reason at all ensures legal and economic security to an independent contractor who existentially depends on such work. A good example, in our opinion, is the Spanish regulation, which, for example, does not allow a contract to be terminated for reason of the pregnancy, illness, or injury of the economic dependent. ${ }^{32}$ The guarantee that work will be provided over a longer period of time often outweighs lower payment, while the guarantee (i.e. protection) of appropriate payment should be underlined as the second element of labour law protection. The latter can be implemented either by means of the institution of a minimum wage or, for example, by guaranteeing payment in an amount that is usual for a certain type, scope, and quality of work of self-employed persons (such an approach has, for example, been adopted in Italy). In Spain, the issue of payment is not given special attention at the legislative level.

31 In terms of values, the function of labour law is understood in a manner such that the system of labour law legal norms should ensure protection to those who need such protection. Therefore, traditionally speaking, labour law protection is not intended for persons who are not in a subordinate position towards an employer. The traditional pattern has been changing with the occurrence and recognition of a new group within the active working population, i.e. economic dependents. It is assumed that economic dependents are vulnerable to such a degree that they are entitled to a certain, limited scope of labour law protection.

32 Art. 16 Estatuto del Trabajo Autonomo, Ley 20/2007 (Self-employed Persons Act); accessible on: https://www.boe.es/buscar/act.php?id=BOE-A-2007-13409 (3.10.2019). 
Also, the Slovenian legislature was aware of the importance of the first two elements of labour law protection when adopting the ERA-l, although they are not the only elements. The protection envisaged by the ERA-I also refers to the area of the prohibition of discrimination and liability for damage. ${ }^{33}$

The termination of contractual cooperation between an economic dependent and a client has two elements. The legislature determined the application of the regulation of minimum periods of notice ${ }^{34}$, which the parties to the contract can extend. A more important area of the regulation of the legal position of economic dependents is the applicability of the unjustified reasons for termination of a contract that are listed in the law. ${ }^{35}$ This is an important provision that was included in the ERA-I on the model of certain foreign regulations, although it is clear that all unjustified reasons will not be legally relevant, as such reasons apply to workers in an employment relationship. For example, reasons connected to membership in a trade union or trade union activities or a change in employer will probably not be applicable, regardless of the fact that also economic dependents are recognised the freedom to join or organise trade unions. The fact that unjustified reasons for termination are determined in the law has a direct consequence, namely that a justified reason is required for the termination of a contract between an economic dependent and the client, which, however, the client does not need to qualify as a business reason, a reason of misconduct, or a reason of incompetence.

As regards the amount of payment for services provided by economic dependents, two options for ensuring appropriate payment were mentioned above, namely by enforcing the institution of a minimum wage or by taking into consideration the usual amount of payment for a certain type, quality, and scope of work. In the ERA-1 the second option is applied, which can be deemed to be more appropriate, so that by complying with collective agreements and general acts that are binding on a client the particularities of individual activities are taken into account. ${ }^{36}$ It is also entirely acceptable that in determining the value of their services, economic dependents include their tax obligations and obligations regarding social security contributions towards the state.

With reference to the prohibition of discrimination, it applies that a client must respect the provisions regarding the general prohibition of discrimination

33 All aspects of a limited labour protection of the economic dependants are determined in Art. 214 of the ERA-1.

34 Art. 94 ERA-1.

35 Art. 90 ERA-1.

36 Art. 214 ERA-1. 
and retaliatory measures, the prohibition of sexual and other harassment, and the particularities of liability for damage in cases involving a violation of the prohibition of discrimination, including the deterrent function of the awarding of damages in such cases. ${ }^{37}$

The last element of labour law protection that the legislature envisaged for economic dependents refers to liability for damage. ${ }^{38}$ Due to the fact that pursuant to the ERA-I there are no particular elements that apply to the liability for damage of employers, this aspect of protection can only be taken into consideration in cases of establishing the liability for damage of economic dependents. The most important particular element is perhaps that an economic dependent is not liable for minor negligence (i.e. carelessness). Regardless of the fact that the ERA-l envisaged the mentioned particular feature with reference to the culpability of economic dependents for inflicting damage, there is justifiable doubt whether such provision is appropriate. A key reason for the fact that the ERA-1 envisages certain particular elements with reference to the liability for damage of workers is that workers carry out work uninterruptedly for a longer period of time and that they are not responsible for the final result and consequently do not bear a business risk. ${ }^{39}$ Their obligation in a civil law sense is an obligation of means, i.e. an input-based obligation. On the other hand, economically dependent self-employed persons usually do not carry out work on the premises of the client and the nature of their work requires that the work be completed, thus they must provide a result. Therefore, they bear a business risk and their obligation is an obligation of result, i.e. an output-based obligation. ${ }^{40}$

\subsection{The identification of an economic dependent}

One of the most important questions of the labour law position of economic dependents that the legislature had to answer with the aim of providing effective statutory regulation thereof was in what manner to establish which self-employed persons are - or when they will become - economic dependents and consequently entitled to the above-described protection. In other words, who should be entrusted with the review of a civil law contractual relationship between two parties in light of the elements that result in economic dependence? A possible

\footnotetext{
Art. 6 and 7 ERA-1.

Art. 170-180 ERA-1.

39 Workers only provide the employer their work, which is directed, supervised, and used by the employer.

40 For more on this, see: Tičar, op. cit. (fn. 15), pp. 162, 163.
} 
manner of identifying such is certainly that individual contracts are reviewed by a body or person competent to do so. This manner is sufficiently complex and it requires more comprehensive and detailed regulation. When adopting the ERA-1, the Slovenian legislature did not have the time or necessary means to provide such regulation. Therefore, it adopted a type of "self-enforcement" principle regarding economic dependence in relation to an individual client. Economic dependents are namely entitled to limited labour law protection if after the end of each calendar or business year they notify their client on whom they are economically dependent of the conditions under which they carry out work. ${ }^{41}$ In order to do so, they must submit to the client all evidence and information necessary to answer the question of the existence of economic dependence. It is an indisputable fact that the entire concept of economic dependence and its implementation in practice depend on the decision of an individual self-employed person to assert economic dependence, i.e. that they notify their key client of the existence of the elements of economic dependence. It is entirely reasonable to have reservations regarding the existing regulation, first, because many self-employed persons are not aware of the possibility of asserting their position as economic dependents, and second, because a certain percentage of self-employed persons will not wish to assert such position, fearing that the client will no longer be willing to work with them.

\section{DEFICIENCIES IN THE STATUTORY REGULATION OF THE POSITION OF ECONOMIC DEPENDENTS}

After roughly six years of experience with legal regulation of economic dependence and the position of economically dependent self-employed persons, the adequacy of the regulation can be assessed and its deficiencies identified. Namely, as is estimated by the labour law experts and national policy maker as well and as some unofficial surveys among the stakeholders show, it is a fact that in practice the institution of economic dependence has not been implemented to the expected extent. ${ }^{42}$ The insufficiently clear legal regulation partly contributed to such. Therefore, in the future changes are expected in this area in the direction of limiting risks for those performing precarious, uncertain work.

41 Art. 214 ERA-1, par. 3.

42 Statistical numbers from the fn. 12 present the estimated numbers of those self-employed, who fulfil conditions for being economic dependents. Unfortunately, the official number of those economic dependents who actually notified such a status to their clients, is unknown. From here comes a conclusion that economic dependence has not been implemented extensively. 
Regardless of the fact whether in the future the legislature decides and perhaps regulates the discussed area in a separate law, with reference to normative regulation, attention should foremost be devoted to the following issues:

i) The need for a clearer definition of the concept of economic dependence in order to facilitate and clarify the delimitation of such position from an employment relationship - in practice the distinction between economic dependence and an employment relationship is namely often not made. Consequently, persons that are in disguised employment relationships assert economic dependence instead of an employment relationship, which would afford them the entire scope of labour law protection. This could also be resolved by targeted awareness raising and informing the participants in the labour market of the differences between the two.

ii) Evaluating the effectiveness of the applicable manner of asserting economic dependence and considering the possible alternatives - the principle of the "self-enforcement" of economic dependence is not effective, as self-employed persons are afraid of the negative reactions of their clients to their asserting economic dependence. The Slovenian labour market is unfortunately heavily influenced by the open resistance of business entities to the restrictions envisaged by labour law legislation. In practice, numerous violations of workers' rights can therefore be detected. An alternative to "self-enforcement" could be determining a state body (e.g. the labour inspectorate) that has jurisdiction to review the nature and content of individual legal-business relationships.

iii) Determining the subject-matter jurisdiction of the labour and social court to resolve disputes related to economic dependence - labour law experts propose determining the subject-matter jurisdiction of the specialised labour court to resolve disputes related to economic dependence. In order to do so, an explicit statutory provision is necessary. Until such provision is adopted, the regular courts have jurisdiction to decide disputes related to economic dependence. As such disputes concern labour law subject matter, it would be more appropriate for them to be resolved before labour courts.

iv) Examining the possibility to provide for effective representation of the interests of economic dependents. Considering the increase in such form of labour, in the future it will be necessary to devote special attention to the possible ways economic dependents could exercise the freedom to join or organise trade unions. Economically dependent self-employed persons may organise with the objective of protecting their interests, however, their organisation does not have the nature of a standard and traditional 
trade union of workers. The latter may only be established by workers in an employment relationship. The regulation of the representation of the interests of economic dependents is also directly connected with concluding collective agreements. Again, also in such cases we cannot speak of standard collective agreements, but of agreements of a similar nature and with similar content, but the fact is that such sui generis collective agreements may be negotiated and may include all the most important features of a relevant protection. The only disputable provisions might have been those determining levels of payment, since such provisions might collide with the free competition rules. ${ }^{43}$

\section{ASSESMENT OF THE RISKS RELATED TO PERFORMING PRECARIOUS WORK}

As mentioned above, the reaction of the state, i.e. the legislature, to the phenomenon of the new group within the economically active population that does not consist of workers in an employment relationship and its inclusion in the ERA-l can be, in general, assessed as appropriate. However, experts have raised the question of whether at that time such regulation was necessary, as the conditions on the labour market were not examined and therefore also an assessment of the necessity of the normative action was not possible. The present regulation of economic dependence and the position of economic dependents also do not provide a suitable basis for systematic monitoring of this type of work and consequently an accurate identification of the legal and actual position of economic dependents cannot be made. Therefore, after more than six years since the recognition of this group within the economically active population it is difficult to assess whether the statutory regulation and its implementation in practice are adequate.

Consequently, it is also difficult to provide a credible assessment of the extent of the precariousness of economic dependents and the assessment provided herein is based on expert considerations and a general understanding of the conditions on the labour market. Certain conclusions are perhaps not entirely reliable. However, they could be used as expert guidelines primarily by the legislature when addressing such type of work in the future.

43 See for instance ruling of the Court of Justice of the EU (CJEU) in case C-413/13 from December the $4^{\text {th }}$ 2014: Genuinely self-employed service providers (not false self-employed), when they set minimum fees for their services in some sort of collective agreement, fall within the scope of art. 101/1 PDEU. This provision deals with prevention, restriction or distortion of competition within the internal market. 
In its global report on the risks of precariousness, the ILO assessed such in light of the following circumstances (seven areas of potential job insecurity): ${ }^{44}$

- employment insecurity;

- earnings' insecurity;

- hours of work and the risk of presentism in the workplace;

- occupational safety and health;

- social security coverage;

- training;

- representation at work.

The assessment of the position of economic dependents through the prism of precariousness primarily depends on whether persons who are in fact economically dependent assert such position in practice. Regardless of the lack of support in the statistics, the statement that the majority of economic dependents do not assert such circumstance with their clients is accurate, which entails that they are not afforded even limited labour law protection as envisaged in the ERA-I. In such cases, the risks related to performing precarious work in all its elements are substantially higher. The legal regulation of economic dependence is intended foremost to limit the risks related to performing precarious work, which, again, is not a guarantee that the precariousness of economic dependents who notify their clients of this fact does not exist. The observations provided below are based on the assumption that self-employed persons have in fact notified their only or one of their clients of the circumstance of economic dependence.

Employment security as the first element of potential precariousness is very important for every economically active person. As economic dependents are not workers in the traditional sense and thus are not afforded the entire scope of protection against dismissal, it is logical that protection for them in this regard is limited. Protection against unjustified reasons for dismissal and complying with minimum periods of notice also in the case of economic dependents appears reasonable from the viewpoint of clients, although a certain risk of the termination of business cooperation remains. An assessment can thus be made that employment security is possible and that the risk of precariousness due to this element is relatively low.

Somewhat different is the element of earnings security, if we only touch upon the question of the amount of payment for services rendered. Regardless of the obligation that with reference to the value of the services rendered by

44 Non-standard employment around the world, International Labour Office, 2016, pp. 19, 20. 
economic dependents collective contracts and general acts which are binding on clients must be respected, we are of the opinion that, under the pressure of competition, the payment for services on the market is in practice often set below these values. The rationale of the legislature to also include in protection the amount of payment, i.e. the value of the services, is clear and distinctly positive; however, the business environment is so demanding that values in practice drop under the required level. Therefore, earnings security in the case of economic dependents is a very strong element contributing to potential precariousness.

The aspects of hours of work and occupational safety and health are connected, as the legal regulation of the hours of work directly affects occupational safety and health. Economic dependents are self-employed persons and limitations regarding working time, breaks, and rests do not apply to them, as these are areas that fall within the organisation of work of the given self-employed person. One of the important elements and advantages of work in the form of self-employment is precisely the greater freedom and autonomy of the individual in determining when and how much to work. Risks related to performing precarious work undoubtedly exist, while the burden on the individual certainly also depends on the amount he or she earns. An individual who needs to work more in order to earn the minimum income is more exposed to risks, also in light of occupational safety and health. With reference to such, it must also be mentioned that the risks related to performing dangerous and unhealthy work are greater in cases in which work requires certain measures or safety equipment that are a financial burden for a self-employed person. An individual that has difficulty ensuring appropriate equipment is also more exposed in the sense of occupational safety and health.

Risks connected to insufficient social security coverage in the Slovenian system primarily stem from the amount that an economic dependent can earn on the market. The scope of social security rights enjoyed by economic dependents is, as a general rule, comparable to that of employees, as self-employed persons are also obliged to join all social security insurances. The difference is in the amount of the basic salary from which contributions are paid, which affects the scope of rights when cases wherein an individual must rely on social security insurance arise. ${ }^{45}$

45 Zakon o prispevkih za socialno varnost, Official Gazette RS, Nos. 5/96, 18/96 ZDavP, 34/96, 87/97 - ZDavP-A, 3/98, 7/98 - odl. US, 106/99 - ZPIZ-1, 81/00 - ZPSV-C, 97/01 - ZSDP, 97/01, 62/10 - odl. US, 40/12 - ZUJF, 96/12 - ZPIZ-2, 91/13 - ZZVZZ-M, 99/13 - ZSVarPre-C in 26/14 - ZSDP-1 (Social Security Contributions Act). 
The lack of training of self-employed persons can be an additional element contributing to potential precariousness particularly in light of carrying out services in the future, as retaining knowledge and skills and acquiring new knowledge and skills importantly affect the position of self-employed persons on the market. This aspect is also directly connected with the ability to bear the financial burden that such training can represent. We estimate that access to training is more limited in the case of economic dependents than in the case of employees due to the financial burden that such represent, as responsible employers namely regularly provide for the training of their employees.

A particularly important element of the position of economic dependents not only in light of potential precariousness is representation at work. Regardless of the fact that pursuant to international and national legal sources the freedom to join or organise trade unions also applies to self-employed persons, it is an undeniably important fact that these are not persons in an employment relationship. As long as economic dependents, perhaps within the framework of an individual activity, do not have representation (i.e. a trade union) that would represent their position on the market and in relationships with clients, their position will be more uncertain. We are of the opinion that some type of representation would be beneficial although the result of successful bargaining between "social partners" could not be understood as classical collective agreement. Finally, a sui generis collective agreement on certain standards of work for economic dependents would considerably reduce the risks related to performing precarious work also stemming from all of the above-discussed elements.

\section{CONCLUSION}

The decision of the legislature to mitigate the growing trend of precarious forms of work also by introducing new groups within the active working population deserves, in principle, to be viewed as positive. Nevertheless, in view of the current conditions on the labour market in Slovenia, the question as to what extent the adopted regulation will contribute to improving the conditions of economic dependents is relevant. The rudiments of the process of the normalisation of the labour market and the development of a stimulating and healthy business environment are in place; however, we must be aware that regulation of the position of economic dependents has a limited influence in this respect.

The transitional provisions of the ERA-l oblige the legislature to regulate issues relating to economic dependents in a separate law in the future, as the regulation in force contains only two articles on the subject. The aspiration was to follow the Spanish model and comprehensively regulate the position 
of economic dependents. In terms of combating precariousness within considered non-standard form of work, it is not so important whether the legislator will proceed to the adoption of a specific law on economic dependency or to modify the existing regulation in ERA-l. More important is, that the country eliminates the identified weaknesses of current regulation and puts in place all the mechanisms necessary to start keeping official statistics on the number and position of economic dependents. This will provide an instrument to successfully address the described risks of precariousness.

\section{BIBLIOGRAPHY}

Adams, A.; Freedland, M.; Prassl, J., The "zero hour contract": regulating casual work, or legitimating precarity, Oxford University working paper, 2014.

Ales, E., The concept of Employee: The position in Italy, in: Wass, B. (ed.), Restatement of Labour Law in Europe, Hart Publishing, Bloomsbury, 2017, pp. 351-375.

Barrios Baudor, G. L., Travail autonome "economiquement dependent" en Espagne, Bulletin de droit comparé du travail et de la sécurité sociale, Comptrasec, 2008, pp. 43-64.

Basselier, R.; Langenus, G.; Walrawens, L., The rise of sharing economy, NBB Economic Review, No. III, 2018, pp. 57-78.

Bečan, I. et al., Zakon o delovnih razmerjih s komentarjem, GV Založba, Ljubljana, 2008.

Brameshuber, E., The "personal work relationship" in Austria, European Labour Law Journal, Vol. 10, No. 3, 2019, pp. 187-197.

Cabeza Pereiro, J., The Status of Self-employed Workers in Spain, International Labour Review, Vol. 148, No. 1, 2008., pp. 91-99.

Garcia Murcia, J.; Rodriguez Cardo, A., The concept of Employee: The position in Spain, in: Wass, B. (ed.), Restatement of Labour Law in Europe, Hart Publishing, Bloomsbury, 2017, pp. 657-675.

Grgurev, I., Ugovor o radu, in: Potočnjak, Ž. (ur.), Radni odnosi u RH, Pravni fakultet u Zagrebu, Organizator, Zagreb, 2007, pp. 14-18.

Jones, B.; Prassl, J., The concept of Employee: The position in the UK, in: Wass, B. (ed.), Restatement of Labour Law in Europe, Hart Publishing, Bloomsbury, 2017, pp. 747-769.

Končar, P., The concept of Employee: The position of Slovenia, in: Wass, B. (ed.), Restatement of Labour Law in Europe, Hart Publishing, Bloomsbury, 2017, pp. 641-655.

Prassl, J., Humans as a service: The promise and perils of work in the gig economy, Oxford University Press, Oxford, 2018. 
Prassl, J.; Risak, M., Uber, TaskRabbit\&Co: Platforms as employers?, Rethinking the legal analysis of crowd work, Comparative Labor Law and Policy Journal, Forthcoming, Oxford Legal Studies Research Paper No. 8/2016, pp. 1-30.

Senčur Peček, D., Samozaposleni, ekonomsko odvisne osebe in obstoj delovnega razmerja, Delavci in delodajalci, Vol. 2-3, 2014, pp. 201-221.

Supiot, A., Beyond employment, Oxford University Press, Oxford, 2005.

Tičar, L., Nova koncepcija ekonomske odvisnosti kot možen dejavnik osebne veljavnosti delovnega prava, Zbornik znanstvenih razprav, Vol. 71, 2011, pp. 175-203.

Tičar, L., Temeljna vprašanja kroga oseb delovnopravnega varstva, Delavci in delodajalci, Vol. 2-3, 2008, pp. 329-343.

Tičar, L., Nove oblike dela - kdo in v kakšnem obsegu naj uživa delovnopravno varstvo, Manet, Ljubljana, 2012.

Wank, R., "Germany", Labour Law in Motion: Diversification of the labour force \& Terms and Conditions of Employment (Reports given at the 7th Tokyo Seminar, March 2004), Kluwer Law, 2005, pp. 19-26.

Waas, B., The concept of Employee: The position in Germany, in: Wass, B. (ed.), Restatement of Labour Law in Europe, Hart Publishing, Bloomsbury, 2017, pp. 251-273.

Williams, C. C.; Horodnic, I. A., Dependent Self-employment. Theory, Practice and Policy, Elgar Publishing, Cheltenham, 2019.

\section{CASE LAW}

Court of Justice of the EU: C-413/13 from December the $4^{\text {th }} 2014$

\section{LEGISLATION}

Companies Act (Zakon o gospodarskih družbah), Official Gazette RS, No. 65/2009 - official consolidated text with amendments

Employment Relationships Act (Zakon o delovnih razmerjih), Official Gazette RS, Nos. 21/2013, 52/2016

Employment Relationships Act (Zakon o delovnih razmerjih), Official Gazette RS, Nos. 42/2002, 103/2007

Estatuto del Trabajo Autonomo, Ley 20/2007 (Self-employed Persons Act); accessible on: https://www.boe.es/buscar/act.php?id=BOE-A-2007-13409 (3.10.2019)

Health and Safety at Work Act in force (Zakon o varnosti in zdravju pri delu), Official Gazette RS, No. 43/2011 
Social Security Contributions Act (Zakon o prispevkih za socialno varnost), Official Gazette RS, Nos. 5/96, 18/96 - ZDavP, 34/96, 87/97 - ZDavP-A, 3/98, 7/98 - odl. US, 106/99 - ZPIZ-1, 81/00 - ZPSV-C, 97/01 - ZSDP, 97/01, 62/10 - odl. US, 40/12 - ZUJF, 96/12 - ZPIZ-2, 91/13 - ZZVZZ-M, 99/13 ZSVarPre-C in 26/14 - ZSDP-1

\section{OTHER DOCUMENTS}

Non-standard employment around the world, International Labour Office, Geneva, 2016.

The scope of employment relationship, Report (V), 2003, available at: http:/ www.ilo.org/public/english/standards/relm/ilc/ilc9l/pdf/rep-v.pdf, p. 10 (3.10.2019).

Green Paper-Modernising labour law to meet the challenges of the 21st century, COM (2006) 708 final, Brussels, 22. 11. 2006 
Sažetak

\section{Luka Tičar*}

\section{KONCEPT EKONOMSKE OVISNOSTI PREMA MOR-u U SLOVENSKOM RADNOM PRAVU}

Slovensko tržište rada već dulje karakterizira činjenica da se radi izvršenja osobnog rada sklapaju ugovori građanskog, obveznog prava. To nije samo po sebi protuzakonito, no povlači određene rizike. Ugovor o radu najprikladniji je i u Republici Sloveniji jedini valjani pravni temelj za obavljanje osobnog, ovisnog i dugotrajnog rada. Svaki osobni rad, naravno, nije ovisan te stoga u odsutnosti elementa osobne podređenosti građansko pravo može biti sasvim odgovarajući i zakonit temelj. Jedan od oblika takvog rada je rad u okolnostima tzv. ekonomske ovisnosti. Riječ je o obliku rada koji uređuje Zakon o delovnih razmerjih (Zakon o radnim odnosima) i koji se temelji na gradanskopravnom ugovoru. Pritom je bitno obratiti pozornost na pravni položaj ekonomski ovisne osobe u svjetlu standarda MOR-a, koji jasno upozoravaju na mogućnost prekarnog odnosa. Čimbenici koji mogu dovesti do prekarnog odnosa su nesigurnost zaposlenja, nesigurnost prihoda, radno vrijeme, sigurnost $i$ zaštita na radu, nedostatno socijalno osiguranje, obučenost te reprezentativnost. Radi smanjenja rizika od prekarnog rada potrebne su izmjene radnog zakonodavstva. Pritom bi trebalo uzeti u obzir barem sljedeće: a) jasnije definirati pojam ekonomske ovisnosti radi lakšeg $i$ preciznijeg razgraničenja prema radnopravnom odnosu; b) ispitati prikladnost postojećeg modela ekonomske ovisnosti $i$ istražiti moguće alternative; c) eksplicitno propisati stvarnu nadležnost radnopravnih sudova glede ekonomske ovisnosti.

Ključne riječi: ekonomska ovisnost, ovisne samozaposlene osobe, prekarni oblici rada, osobni djelokrug radnog prava

* Dr. sc. Luka Tičar, docent Pravnog fakulteta Sveučilišta u Ljubljani, Poljanski nasip 2, 1000 Ljubljana, Slovenija; luka.ticar@pf.uni-lj.si;

ORCID ID: orcid.org/0000-0001-5793-6270 